\title{
Dimensions of Women Empowerment Through Microfinance
}

\author{
Rejoice Solomon, Ranu Sharma
}

\begin{abstract}
Microfinance institutions' plays a crucial role for the upliftment of rural women. Women are the key of a nation development. So in order to attain the development of a nation there is need to empower the women of our nation. Microfinance institutions have always seen as a tool of poverty alleviation as they provide the facility of financial services to the needy and the weaker section of the society without any collateral security. And it proved itself as a tool of poverty alleviation. Thus it also a vaccine for women empowerment. Empowerment of women can be done with the help of Self-Help-Group. Where 10-12 women form a group with same socio-economic background and they were trained, educated so they may uplift their family, their society and ultimately the nation as whole. The objective of this paper is to understand the different dimension of women empowerment with the help of microfinance. And from the study it was seen women should be psychologically, economically and Socially Empowered and it all comes with the help of microfinance. And microfinance proved that it a vaccine for the empowerment of women.
\end{abstract}

Keywords: Women Empowerment, Self-help-Group, Microfinance, Dimensions.

\section{INTRODUCTION}

The concept of microfinance developed by Mohammed Yunus in the year 1974 when the people of Bangladesh fall into the trap of famine. But it was acceptable by the government of Bangladesh in the year 1983 as a Grameen Bank Model. They used to make small group of 7 to 12 women who have a same socio-economic background granting them loan without any collateral security and that group is known as Self-Help-Group. In India reserve Bank of India (RBI) approved in the year 1992. It is also known as Bankers to the Poor.

Empowerment of women fully depends upon the, microfinance as it then one who works at grassroots level providing the awareness of their right, the importance of women empowerment for the nation. How they contribute toward the nation development. Women empowerment is not a new concept it was in the year 1880's also. But that time they didn't get proper guidance but now with the help of microfinance they are getting know their rights.

Manuscript received on March 23, 2021.

Revised Manuscript received on May 24, 2021.

Manuscript published on May 30, 2021.

* Correspondence Author Studies, Poornima University, Jaipur (Rajasthan) India. Email: rejoicesoloman.sony@gmail.com

Dr. Ranu Sharma, Associate Professor, Department of Management Studies, Poornima University, Jaipur (Rajasthan) India. Email: ranu.sharma@poornima.edu.in

(C) The Authors. Published by Blue Eyes Intelligence Engineering and Sciences Publication (BEIESP). This is an open access article under the CC BY-NC-ND license (http://creativecommons.org/licenses/by-nc-nd/4.0/)
Rejoice Solomon*, Research Scholar, Department of Management

Women empowerment and nation development are linked together without women empowerment a nation can't be develop. Thus microfinance institutions are working for the betterment for nation by empowering the weaker, poorer women of the society.

\section{REVIEW OF LITERATURE}

Many studies have been done out to understand the dimensions of women empowerment. Microfinance plays a vital role to empower the women and they target only women because there repayment is good and they repay on time without any delay. And in order to identify the different areas of women empowerment though microfinance with the help of self help group a study was carried out. Women are the key of Nations development through microfinance. Many studies it has also been found how microfinance helps the nation for its development by targeting the rural women.

Mehra, et al., 2010 presented an empirical study to analyze role of women empowerment through self help group. Discussed the income generated activities initiated by SHG's members and its problems. For the purpose of study an analytical research survey was conducted through questionnaire among 80 SHG's members of Indore district, Madhya Pradesh. The empowerment of women was analyzed under 4 parameters they are; influence over Economic resources of the family, women's own development, decision pertaining to general welfare of the family and influence over local political activities. Majority of the respondents said that they were facing the problem of over burden with responsibilities, high interest rate by banks. Author concluded that SHG'S are contributing rapidly for the growth of women and also for the Economic. Venkatesh \& Kala, 2010 presented an empirical study on Economic empowerment of women after joining SHG'S For the purpose of study an analytical research survey was conducted through questionnaire among 134 SHG'S members from south districts of Tamilnadu. The data was analyzed on the basis of various perspectives like; age, reason for joining SHG'S, before \& after monthly income, amount of loan, repayment of loan. The collected data was analyze by using percentage, Author concluded that after joining SHG'S there is an improvement among the women, SHG'S's in south Tamilnadu worked very well it goes in such the SHG'S's of Tamilnadu will success. Jain,2012 presented an empirical study to assess the impact of microfinance on empowering women of Udaipur district Rajasthan, framed three hypotheses to analyze the relationship of age, education, period of membership with respect to empowerment of women. 
An analytical research survey was conducted through questionnaire among 100 respondents to evaluate the impact of microfinance among women in three dimensions of empowerment i.e. Economic, Social and political. Authors concluded that respondents were unable to face the financial crisis in the family and there is a high level of political empowerment among women as compared to Economic empowerment and there was a poor level of Social empowerment. Indhumathi \&Palanivelu, 2013 presented a study on women empowerment through SHG'S by testing three hypotheses that analyses the relationship of education with training facility, with banker's attitude and with the income of the members after joining SHG'S. The study was carried out in 100 SHG'S members of Pollachi block in Coimbatore district, Tamilnadu, who were interviewed. Author concluded that majority of the respondents were satisfied with their income, expenditure and employment were increased ant they feel their status has been improved. Author also suggests that training facility should be provided banks procedure should be minimized, awareness programme should be conduct. Farooqui, 2013 presented an empirical study to analyze the role of microfinance institution in promoting and distributing micro insurance product. Framed two hypotheses to analyze the significance role of microfinance with awareness of micro insurance product and with micro finance institutions. For the purpose of study an analytical research survey was conducted through questionnaire among 140 respondents of Allahabad, Uttar Pradesh. It was found the respondents were not much aware regarding the micro insurance product; microfinance institutions were facing the problem in creating awareness and distributing products because of lack of illiteracy, modern technology, resources. Author concluded that the role of microfinance institutions in promoting and distributing micro insurance products were ineffective thus he suggests that microfinance institutions should laid the foundation of insurance among BPL and companies should launch new innovative and attractive product. Maurya, 2014 presented a study to know the impact of microfinance on poverty eradication through SHG'S. Discussed the SocioEconomic impact of microfinance on savings and borrowings pattern among SHG'S members. Most of the researcher discussed the projects launched by NABARD. For the purpose of study both primary and secondary data have been used. An analytical research survey was conducted upon 125 SHG'S members through interview among four regions i.e. Patti, Kunda, Sandwa and Lalgan of Pratapgard district in Uttar Pradesh, India. After joining SHG'S the savings and income of the respondents were increased and they started towards non-farm activities, dependencies on moneylenders were reduced and the loan which they avail was for income generating activities. Author concluded that SHG'S's not only provided the financial services but also works better in terms of creating awareness \& empowerment. SHG'S played an important role for the development of Uttar Pradesh as it improved the Economic conditions, developed Social conditions of people. Das \& Baishya, 2015 had presented a study on role of SHG'S in empowering Rural Women. For the purpose of study both primary and secondary data have been used. The secondary data are collected from various books, journals, articles, working papers, block office records etc. Collected through structured interview among 10 SHG'S of Rani Block of kamrup district in Assam Discussed Economic and Social condition of women. It has shown a positive impact on the women of Assam.

\section{OBJECTIVES OF THE STUDY}

The objective of the present study is to identify the Dimensions that help in the empowerment of women through microfinance self help group programme.

\section{RESEARCH METHODOLOGY}

For the purpose of study secondary data was used. The data was collected from the reports, journals, and books.

\section{* Different dimensions of women empowerment through Microfinance}

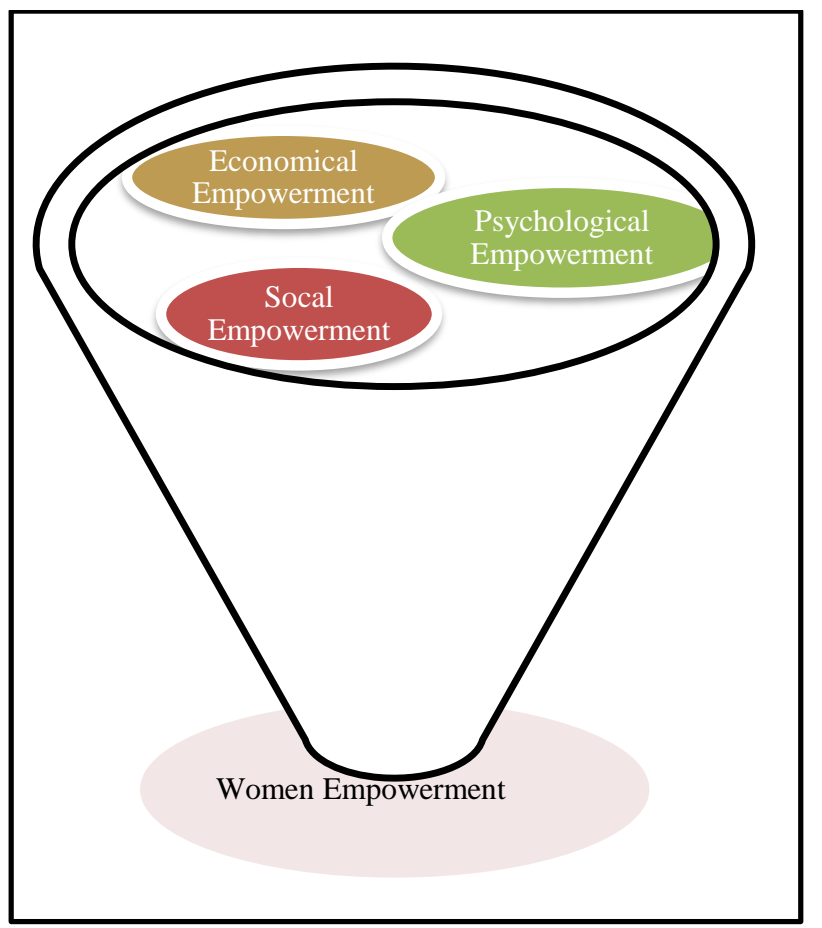

Fig1.1 Dimensions of Women Empowerment

Women empowerment is necessary and microfinance empowering the women through it Self-Help-Group programme. There are three important areas where women should empower, they are: - Psychological, Economical, Social. These three aspects of empowerment help women to empower completely.

\section{Psychological Empowerment}

Psychological empowerment of women helps her to take own decision with the interference of other. A women is called to be psychologically empowered when she is able or stand for herself, taking her choice independently and for this microfinance helps a lot by organising a camping for make her psychologically empowered. Psychological empowerment of women helps her to make her choice and in case if her choice is not has a positive impact then she should be handle that also.

Published By:

Blue Eyes Intelligence Engineering \& Sciences Publication

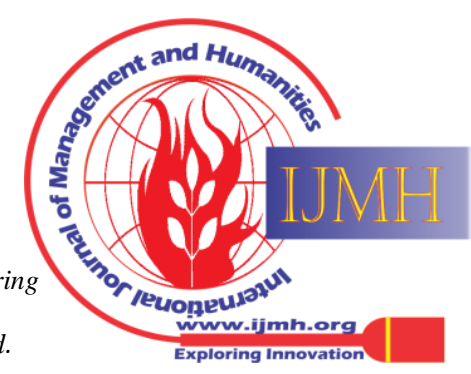


Microfinance help s women to empower psychologically by providing the awareness campaign on the health related problems, nutrition and balanced diet. It all comes when she is know what is right and wrong and making her decision independently. The Psychological empowerment means when a women her takes her choice with the influence of any other. When she has a control on her decision and enough cable to understand what is right and wrong. And it will happen only with the help of microfinance self-help group where they gather for the credit purpose but through they used to give them the facility training to empowerment themselves and it has seen from the literature review part also that microfinance has a positive impact on the women empowerment.

\section{Social Empowerment}

A women is said $\mathrm{t}$ be socially empowered when participating in social activities, moving freely, participating in social gather freely presenting her opinion in group. For this microfinance helped them a lot to make them socially empower. Because then she will be able to present herself without any hesitation. Social empowerment helps women to raise her voice against the domestic violence. Thus social empowerment is necessary and plays a important in the life of women. A socially empower women is being able to solve not only her problems but also the problems of society. it all comes only with the help of microfinance self help group programme.

\section{Economical Empowerment.}

Contribution of women in the economy makes her independent and empower. For this microfinance play a crucial role by helping to start their own business or by arranging the facility of marketing their product so that their standard of living may increase. Microfinance helps women in the income generating activity by different schemes and policies launched by the government because an economic empowerment of women develops a nation. Economically empowered women build a nation strong. If women is economically empowered the nation will develop itself. Women is the foundation of the development they are the base without them a nation can't be empowered. Microfinance help women to become an entrepreneur and self dependent hand help a lot in their income generating activity.

\section{* Stages of Women Empowerment}

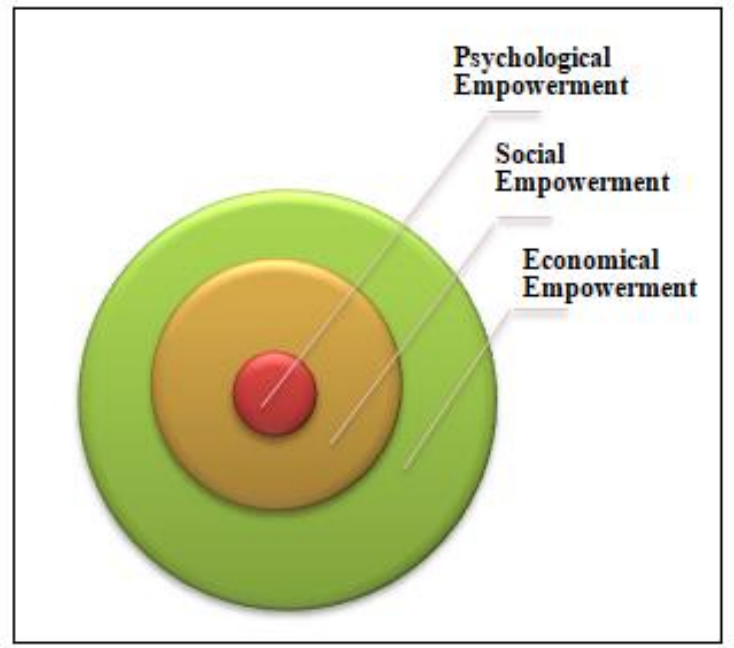

Fig 1.2 Stages of empowerment
The above figure 1.2 shows the stages of empowerment a women. Empowerment is necessary but there should be proper work in order to make her completely empower. $\mathrm{T}$ make her women economically empower it is necessary to make her psychologically empower then only she will be empowered socially and economically. Without psychological empowerment social and economical can't take place. Therefore one microfinance should work on to make her psychologically empower.

\section{CONCLUSION}

Microfinance has proved a vaccine for women empowerment and also it has a positive impact on the women empowerment. Women become socially economically and psychologically empowered. Empowerment of women help s a lot for the development of a nation .from the study the three different dimension of empowerment studied and also the stages of empowered which should be followed to make her empower in a proper manner.

\section{REFERENCES}

1. Jaya Mehra, Sandhya Choudhary, N. K. Punjabi \& K. L. Dangi, "Role of SHG'S in empowerment of rural women in Indore block of Madhya Pradesh", Raj J. Extn. Edu. 17 \& 18: 118-120, 2009 \& 2010.

2. Dr. J. Venkatesh, Ms.k.Kala, "Empowering rural women all the way through Self Help Group", international journal of management, ISSN 0976-6502,volume 1, no.2, oct- Nov 2010. Pp.156-163.

3. Dr.Dhiraj Jain, Dr.Dhiraj Jain, "does microfinance empower rural women?-A empirical study in Udaipur district, Rajasthan", International Refereed Research Journal, Volume 3, Issue 2(1), April 2012.

4. Mrs. C. Indhumathi, Dr. P. Palanivelu, "women empowerment through self - help group", global research analysis, Volume: 2, Issue:6, June 2013.

5. Harikesh Maurya, "Impact of microfinance on poverty eradication through SHG'S's", international journal of Social research, Volume 3, issue 12, December, 2014.

6. Mrs. Eli kumari Das, Ms. Dharitri Baishya, " Role of Self-Help Groups in Empowering Rural Women: A case study on selected SHG'Ss in Rani Block of Kamrup District of Assam", Journal of Economics and Finance, Volume 6, Issue 2, PP 27-31, Mar.-Apr. 2015.

\section{AUTHORS PROFILE}

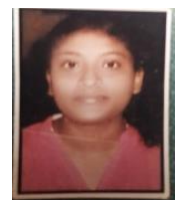

Rejoice Solomon, Research Scholar, Department of Management Studies Poornima University Jaipur, Rajasthan India

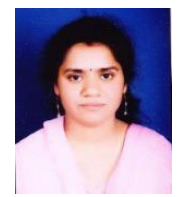

Dr. Ranu Sharma, Associate Professor, Department of Management Studies Poornima University Jaipur, Rajasthan India

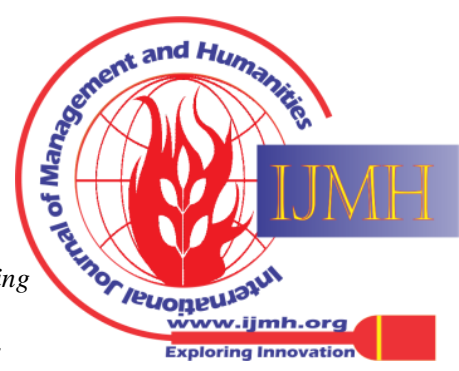

